\title{
Genetical relationships between malathion-resistance and fenthion- resistance in larvae of Culex pipiens pallens Coquillett ${ }^{1)}$
}

By

\author{
Takeo Tadano ${ }^{2}$
}

\section{INTRODUCTION}

The mode of inheritance of malathionresistance has been shown to be monofactorial in Culex pipiens fatigans by Umino and Suzuki (1966), and in C. p. pallens by Tadano (1969) who demonstrated that the resistance factor was linked to chromosome 2 with a crossover unit of $40-43 \%$ from $r u$ (ruby eye).

A multiple-resistant colony of C. p. pallens was found in Hyogo Prefecture, Japan (Suzuki, 1968), which was cross-resistant to 6 organophosphorus insecticides including malathion and fenthion, and cross-tolerant to 4 other organophosphorus insecticides such as Dursban which had never been applied in the field. This study presents genetical relationships between malathion- and fenthion-resistance in a $C . p$. pallens colony which was derived from the multiple-resistant colony mentioned above.

\section{MATERIALS AND METHODS}

Two organophosphorus insecticides, malathion and fenthion, and the following two colonies were used in this study :

NMFR : a malathion- and fenthion-resistant colony without any visible mutant of $C$. p. pallens which was submitted to the larval selection with malathion for 10 generations and thereafter with fenthion for 5 further generations. The $\mathrm{LC}_{50}$ was 0.90 ppm for malathion and $0.17 \mathrm{ppm}$ for fenthion.

1) This study was supported by Public Health Service Research Grant \# CC 00168 from National Communicable Disease Center, Atlanta, Georgia.

2) 只野長夫 : Department of Parasitology, the Institute of Medical Science, the University of Tokyo, Tokyo, Japan (Chief : Prof. M. Sasa). $r u$ (ruby eye): an autogenous colony of $C$. pipiens which is a chromosome-2 marker strain susceptible to both malathion and fenthion, the $\mathrm{LC}_{50}$ being 0.07 ppm for malathion and 0.0034 ppm for fenthion.

Crossing experiments were all made in cages $(20 \times 20 \times 20 \mathrm{~cm})$ at a temperature of $25 \pm 1^{\circ} \mathrm{C}$ and the adults were fed on ca. $10 \%$ sucrose solution, the female mosquitoes also on mice. Reciprocal crosses were made between the $r u$ strain and NMFR strain, although from the cross of $r u$ males and NMFR females sufficient numbers of offspring could not be obtained for the backcrossing due to cytoplasmic incompatibility, and then the $F_{1}$ hybrids from the cross between $r u$ females and NMFR males were reciprocally backcrossed with the $r u$ strain, using 100-150 individuals of each sex for one cross. All susceptibility tests were performed on larvae in the $3 \mathrm{rd}$ or 4 th instar stage by the standard method for mosquito larvae (WHO Expert Committee on Insecticides, 1960) at a temperature of $23-24^{\circ} \mathrm{C}$.

\section{RESULTS}

When the females of the rustrain were crossed with the males of the NMFR strain, of which larvae were resistant to both malathion and fenthion, the $F_{1}$ hybrids were intermediate in resistance to malathion and fenthion, though much closer to the resistant parent (Figs. 1 and 2 , in Fig. $2 r u$ III, IV, $F_{1}$ III and IV are the dosage-mortality (d-m) lines for the third and fourth instar larvae of the $r u$ strain and $F_{1}$ hybrids respectively). The $d-m$ lines for the backcross offspring, which were produced by reciprocally crossing the $F_{1}$ hybrids with the $r u$ strain, have inflexions at about 


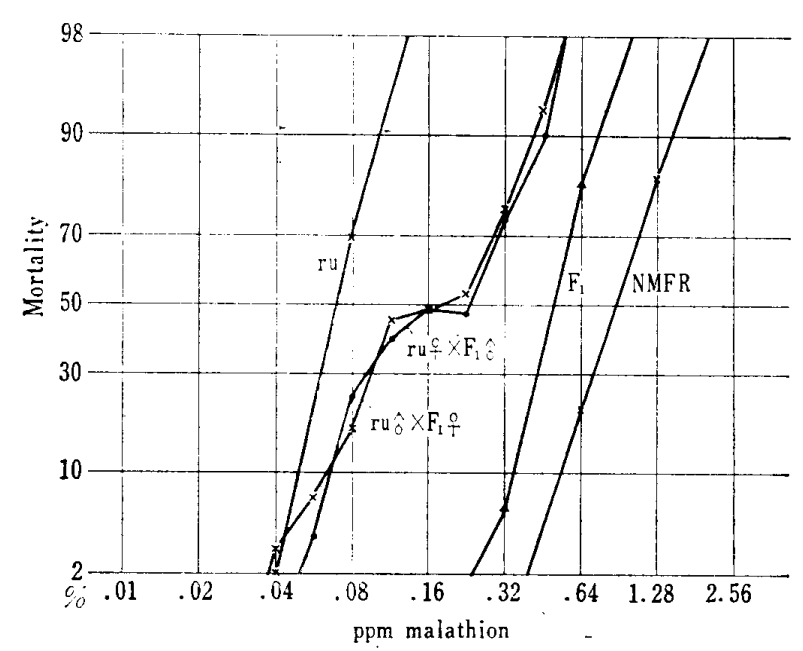

Fig. 1

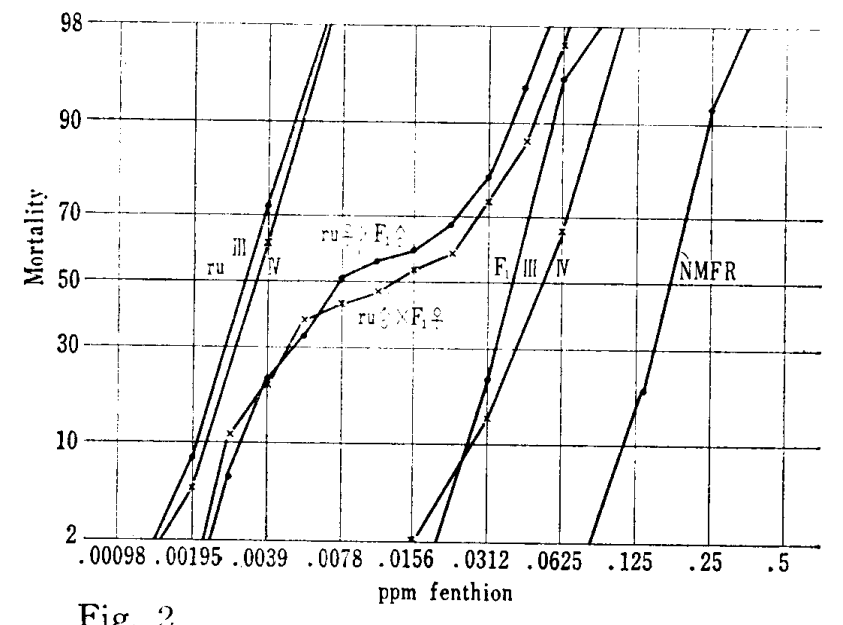

Fig. 2

$50 \%$ mortality level for malathion and fenthion, indicating that the backcross offspring segregated into the susceptible homozygotes and the heterozygotes in a $1: 1$ ratio. These facts prove that each of the resistance to malathion and to fenthion was monofactorial, and the factors for the resistance were incompletely dominant.

In order to find relationships between gene loci of the factors for malathion- and fenthionresistance, the following procedure was performed :

1. The backcross offspring in the third instar, after separation of the larval eye colours into $r u$ and wild type, were exposed to a discriminating dose of $0.0078 \mathrm{ppm}$ fenthion for 24 hours (see Fig. 2) to remove the fenthion-susceptible phenotypes $(++$ and $+M R$, in which $M R$ represents a malathion-resistance factor) and none of the heterozygotes ( $F R M R$ and $F R+$, $F R$ here represents a fenthion-resistance factor).

2. After the heterozygous survivors had been fed in deionized water for 24 hours, they were again exposed to a discriminat- ing dose of $0.16 \mathrm{ppm}$ malathion for another 24 hours, which was known to kill all the malathion-susceptible homozygotes $(F R+)$ but to allow $91.8 \%$ of the heterozygotes $(F R M R)$ to survive.

After the above procedure, the data were adjusted to compensate for the discriminating dose of malathion killing $8.2 \%$ of the heterozygotes $(F R M R)$ and then summarized in Tables 1 and 2. The tables show that the

Table 1. Offspring of backcross $r u$ 우 $\times F_{1}$ $(r u$ 우 $\times$ NMFR 항

\begin{tabular}{|c|c|c|c|c|c|c|c|}
\hline \multicolumn{4}{|c|}{ Phenotypes } & \multicolumn{4}{|c|}{ Phenotypes } \\
\hline$r u$ & $F R$ & $M R$ & 338 & + & $F R$ & $M R$ & 717 \\
\hline$r u$ & $F R$ & + & 147 & + & $F R$ & + & 31 \\
\hline$r u$ & + & $M R$ & 194 & + & + & $M R$ & 34 \\
\hline$r u$ & + & + & 452 & + & + & $\begin{array}{c}+ \\
\text { Tota }\end{array}$ & $\begin{array}{r}791 \\
2704\end{array}$ \\
\hline
\end{tabular}

Recombination between $r u$ and $F R=47.8 \pm 1.0 \%$ Recombination between $r u$ and $M R=50.0 \pm 0.9 \%$ Recombination between $F R$ and $M R=14.9 \pm 0.7 \%$

Table 2. Offspring of backcross $r u+\times F_{1}$ $(r u$ 우 $\times$ NMFR 훙) 오

\begin{tabular}{|c|c|c|c|c|c|c|c|}
\hline \multicolumn{4}{|c|}{ Phenotypes } & \multicolumn{4}{|c|}{ Phenotypes } \\
\hline$r u$ & $F R$ & $M R$ & 1593 & + & $F R$ & $M R$ & 2362 \\
\hline ru & $F R$ & + & 394 & + & $F R$ & + & 129 \\
\hline$r u$ & + & $M R$ & 381 & + & + & $M R$ & 107 \\
\hline$r u$ & + & + & 1525 & + & + & $\begin{array}{c}+ \\
\text { Tota }\end{array}$ & $\begin{array}{r}1945 \\
=8436\end{array}$ \\
\hline
\end{tabular}

Recombination between $r u$ and $F R=48.2 \pm 0.5 \%$ Recombination between $r u$ and $M R=48.2 \pm 0.5 \%$ Recombination between $F R$ and $M R=12.1 \pm 0.1 \%$ crossover unit between $r u$ and $F R$ was $47.8 \%$ in the males and $48.2 \%$ in the females, and the crossover unit between $r u$ and $M R$ was $50.0 \%$ in the males and $48.2 \%$ in the females, while the value for $F R-M R$ was $14.9 \%$ and $12.1 \%$ in the males and females respectively. It is therefore concluded that a malathion-resistance factor is located at crossover distances of $48.2-50.0 \%$ from $r u$ and of $12.1-14.9 \%$ from the fenthion-resistance factor which is linked to $m$ with a crossover value of $48 \%$.

\section{DISCUSSION}

Monofactorial inheritance has been found in malathion-resistance in Culex $p$. fatigans (Umino and Suzuki, 1966) and C. p. pallens (Tadano, 1969), and in fenthion-resistance in C. p. pallens (Suzuki and Matsunaga, personal communication); this study confirmed the 
previous finding of the mode of inheritance of malathion-resistance and fenthion-resistance in the $C . p$. group.

The problem arose at the start of this experiment as to how closely the genes for resistance to malathion and fenthion are located in the multiple-resistant colony, and both the genes were found to be unexpectedly far linked with a crossover value of $12-15 \%$. This fact is interesting as compared with the housefly in which Nguy and Busvine (1960) assumed that the genes for malathion-resistance and parathion-resistance were either alleles or closely linked.

There was some difference between the values of crossover for $r u-M R$ previously reported (40-43\%) (Tadano, 1969) and mentioned in this paper $(48-50 \%)$, though the colonies used in this study were originally the same as those employed in the previous study. Dorval, C. and Brown, A. W. A. (personal communication) found the crossover unit for $r u-M R$ to be $42 \%$, whereas it was approximately $48 \%$ in this study. These results indicate that both the resistance genes are located too far from the $r u$ gene to calculate the precise loci. It is now really unfortunate for the genetics of this species that there is a basic shortage of genetic markers especially of chromosome 2 for analyzing in more detail the mode of inheritance of resistance to the organophosphorus compounds. Determination of gene order or map distances awaits further crossing experiments using more suitable visible markers.

\section{SUMMARY}

1. Monofactorial inheritance of resistance to malathion and fenthion was proved in the colony of Culex p. pallens which showed 13fold resistance to malathion and 50 -fold resistance to fenthion after 10 generations of the larval selection with malathion and 5 further generations with fenthion; the factors for malathion- and fenthion-resistance were incompletely dominant.

2. Genetical linkage relationships were investigated between malathion-resistance and fenthion-resistance in this colony; the results show that a malathion-resistance factor is located at crossover distances of $48-50 \%$ from $r u$ on chromosome 2 , though of $40-43 \%$ from $r u$ in the previous study, and of $12-15 \%$ from the fenthion-resistance factor linked to $r u$ with a $48 \%$ crossover unit.

\section{ACKNOWLEDGEMENTS}

The author wishes to express his gratitude to Prof. M. Sasa, Director of the Institute of Medical Science, the University of Tokyo, and to Dr. T. Suzuki, Lecturer at the Graduate School, the University of Tokyo, for their advice and encouragement in the course of this work. $\mathrm{He}$ is especially grateful to Dr. A. R. Barr, University of California, Los Angeles, California, U. S. A., for his supply of the marker strain used in this study, and to Dr. M. Tsukamoto, University of Nagasaki, Nagasaki, Japan for his critical reading of the manuscript.

\section{REFERENCES}

-1) Nguy, V. D. and Busvine, J. R. (1960): Studies of the genetics of resistance to parathion and malathion in the housefly. Bull. Wld Hlth Org. $22: 531-542$. - 2) Suzuki, T. (1968) : A note on a multiple-resistant or -tolerant colony of Culex pipiens to organophosphorus insecticides. Jap. J. Sanit. Zool., 19(2) : 98-100. -3) Tadano, T. (1969): Genetical linkage of malathion-resistance in Culex pipiens L. Japan. J. Exp. Med. 39(1), (in press). -4) Umino, T. and Suzuki, T. (1966): Studies on the mode of inheritance of malathionresistance in larvae of Culex pipiens fatigans. Jap. J. Sanit. Zool., 17(3) : 191-195.

\section{摘 要}

Culex pipiens pallens Coquillett の幼虫 に㧍ける malathion 抵抗性とfenthion 抵抗性との遺伝的関係

兵庫県下で採集されたCulex pipiens pallens の有機 燐殺虫剂抵抗性のコロニーを malathion と fenthion で 5 代から 10 代淘汰したコロニーと殺虫剂感受性で第 2 染 色体 marker である ru (ruby eye) コロニーとを用い て次の結果を得た.

1. Culex p. pallens の幼虫の malathion 抵抗性も fenthion 抵抗性も夫々，不完全優性の単一因子によつ て遺伝する.

2. これらの抵抗性因子は第 2 染色体上にあつて，ru (ruby eye) 因子から遠く離れているが，malathion 抵 抗性因子と fenthion 抵抗性因子とは $12 \%$ 力 $515 \%$ （交 叉価）ぐらい離れて存在すると結論された。

3. ru 因子, malathion 抵抗性因子及び fenthion 抵 抗性因子の遺伝子配列順序は別のより適当な marker を 用いて決定されなければならない。 